\title{
Susceptibility of Selected Woody Plants to Pelleted Picloram
}

\author{
LYNN M. KITCHEN, C.J. SCIFRES, AND J.L. MUTZ
}

\begin{abstract}
Picloram pellets, aerially applied at $1.1 \mathrm{~kg} / \mathrm{ha}$ in the spring to South Texas mixed-brush, effectively controlled spiny hackberry and pricklypear, and $2.2 \mathrm{~kg} / \mathrm{ha}$ temporarily controlled blackbrush acacia. However, agarito, desert yaupon, lotebush, Texas persimmon, and whitebrush were only slightly susceptible to soil applications of picloram, and honey mesquite and creeping mesquite were tolerant. Range site exerted a significant influence only with initial defoliation of twisted acacia. Although canopy reduction of twisted acacia after one growing season was higher on Shallow than on Rolling Blackland or Claypan Prairie range sites, it was apparently only moderately susceptible to pelleted picloram. Shredding prior to pellet applications did not improve the level of brush control compared to applying the picloram to undisturbed brush stands. There was no consistent difference in brush control within an application rate between $5 \%$ or $10 \%$ active ingredient formulations of picloram pellets.
\end{abstract}

Chemical brush control on rangeland, especially in Texas, is accomplished largely with sprays of hormone-type herbicides. However, aerial application of sprays containing 2,4,5-T [(2,4,5-trichlorophenoxy) acetic acid], picloram (4amino-3,5,6-trichloropicolinic acid), dicamba $(3,5-$ dichloro-o-anisic acid), and similar herbicides is often limited because of the potential for physical spray drift and/or movement of vapors to herbicide-susceptible agronomic crops, ornamentals, or vegetables. Also, extensive acreages of brushland in Texas are not treated each year because foliar herbicide applications must be carefully timed to coincide with the phenological stage of maximum susceptibility of the brush. This stringent requirement usually reduces the spray season for species such as honey mesquite (Prosopis glandulosa var. glandulosa) to fewer than 60 days annually (Scifres 1973). Moreover, many of the woody species in mixed stands such as the Prosopis-Acacia complex of the South Texas Plains, may not be highly susceptible to the sprays at the time honey mesquite is most susceptible.

Because of the limitations of sprays, recent research has emphasized development of dry herbicide formulations, particularly pellets, for brush management. Potential of physical drift is greatly reduced, and the hazards of volatility are essentially eliminated, when pellet formulations are used.

In contrast to timing requirements for maximum activity

Authors are former Research Assistant, Professor, and Assistant Research Scientist, Department of Range Science, Texas A\&M University, College Station, 77843 . Kitchen is now a Graduate Research Assistant, Agronomy Department, University of Kentucky, Lexington, 40506. The authors gratefully acknowledge Julia Scifres for typing and preparing this manuscript. Appreciation is extended to Drs. L.F. Bouse and $R$.W. Bovey for allowing use of their research aircraft for application of the herbicide. Also, David Embry, Rob Gordon, Jerry McAtee and Carl Mohr helped with plot installation and evaluation. This research was partially supported financially by the 74 Ranch, Campbellton. Texas and the P.H. Welder Ranches, Victoria, Texas.

Published with approval of the Director, Texas Agricultural Experiment Station as TA-14863.

Manuscript received February 9, 1979. of herbicide sprays, pellets can apparently be applied during a relatively long period each year (Bovey et al. 1972; Meyer et al. 1976; Meyer et al. 1978). The apparent requisites for activity of soil-applied herbicides are rainfall adequate for dissolution and movement of phytotoxic amounts of chemical into the soil, active plant growth to ensure root absorption, and sufficient residual activity for adequate exposure time of the target species to phytotoxic levels of the herbicide (Scifres 1972b). Thus, pelleted herbicides might be applied during any time of the year, except during summer drought, with expectations of effective results, depending on rainfall and species susceptibility (Bovey et al. 1972; Meadors. et al. 1978).

Picloram is taken up by the foliage and/or the roots of many species and is relatively persistent in most soils, especially those containing low percentages of organic matter and clay (Bovey and Scifres 1971). Picloram is formulated as pellets containing either $5 \%$ or $10 \%$ active ingredient. Individual-plant applications of $10 \%$ picloram pellets effectively control Texas persimmon (Diospyros texana) (Scifres 1975b), lotebush (Ziziphus obtusifolia) (Scifres and Kothmann 1976), redberry juniper (Juniperus pinchotii) (Scifres 1972a), and Macartney rose (Rosa bracteata) (Meyer et al. 1976; Scifres 1975a). Broadcast applications of $10 \%$ picloram pellets at 2.2 to $4.5 \mathrm{~kg} / \mathrm{ha}$ also effectively control redberry juniper (Robison and Cross 1970). Broadcast picloram sprays at conventional application rates do not effectively control Texas persimmon or lotebush (Bovey et al. 1970).

The relative effectiveness of aerial applications of picloram pellets for control of a broad spectrum of woody plants in mixed stands has not been thoroughly studied. Also, recent research indicated that broadcast applications of the pellets were more effective for Macartney rose control when applied immediately after burning of Coastal Prairie than for control of undisturbed stands (Gordon 1976). It was postulated that the picloram was more readily absorbed by roots after the mature topgrowth was removed than by undisturbed Macartney rose plants.

The objectives of this research were to evaluate (1) the susceptibility of various woody species to aerial applications of pelleted picloram, and (2) the influence of shredding prior to applications of picloram pellets on control of the woody plants.

\section{Study Site Descriptions}

Two experiments were conducted in South Texas mixed-brush communities near Campbellton about $80 \mathrm{~km}$ south of San Antonio. Major brush species included honey mesquite, whitebrush, creeping mesquite (Prosopis reptans), blackbrush acacia (Acacia rigidula) twisted acacia (Acacia tortuosa), catclaw acacia (Acacia 
Table 1. Textural classes, organic matter content (\%), and $\mathrm{pH}$ of soil from various depths $(\mathrm{cm})$ from the Rolling Blackland, Claypan Prairie, and Shallow range sites near Campbellton, Texas.

\begin{tabular}{|c|c|c|c|c|c|}
\hline \multirow[b]{2}{*}{ Depth } & \multirow[b]{2}{*}{$\mathrm{pH}$} & \multirow{2}{*}{$\begin{array}{l}\text { Organic } \\
\text { matter }\end{array}$} & \multicolumn{3}{|c|}{ Textural components $(\%)$} \\
\hline & & & Sand & Silt & Clay \\
\hline \multicolumn{6}{|c|}{ Rolling Blackland } \\
\hline $0-3$ & 6.9 & $4 . \ddot{i}$ & 31 & 20 & 49 \\
\hline $3-8$ & 7.3 & 2.9 & 26 & 27 & 47 \\
\hline $8-15$ & 7.4 & 2.5 & 28 & 22 & 50 \\
\hline $15-30$ & 7.4 & 2.3 & 28 & 25 & 47 \\
\hline $30-46$ & 7.5 & 2.1 & 22 & 23 & 56 \\
\hline \multicolumn{6}{|c|}{ Claypan Prairie } \\
\hline $0-3$ & 5.4 & 3.2 & 46 & 20 & 34 \\
\hline $3-8$ & 5.5 & 2.6 & 43 & 23 & 34 \\
\hline $8-15$ & 5.7 & 2.1 & 34 & 26 & 39 \\
\hline $15-30$ & 6.0 & 2.2 & 25 & 21 & 53 \\
\hline $30-46$ & 6.5 & 2.1 & 25 & 20 & 55 \\
\hline \multicolumn{6}{|c|}{ Shallow } \\
\hline $0-3$ & 7.4 & 3.2 & 48 & 16 & 37 \\
\hline $3-8$ & 7.4 & 2.4 & 30 & 25 & 45 \\
\hline $8-15$ & 7.4 & 2.2 & 27 & 25 & 48 \\
\hline $15-30$ & 7.4 & 1.8 & 22 & 22 & 56 \\
\hline $30-46$ & 7.6 & 1.5 & 22 & 19 & 58 \\
\hline
\end{tabular}

greggii), spiny hackberry (Celtis spinosus), Texas pcrsimmon, Carolina wolfberry (Lycium carolinianum), Berlandier wolfberry (L. berlandieri) pricklypear (Opuntia sp.), lotebush, agarito (Berberis trifoliolata), desert yaupon (Schaefferia cuneifolia), and knifeleaf condalia (Condalia spathulata). Canopy cover of the brush stands ranged from 21 to $90 \%$, depending on range site, at initiation of the research.

The study area near Campbellton was stratified into range sites designated by the Soil Conservation Service, as the Shallow Range Site, Claypan Prairie Range Site, and Rolling Blackland Range Site. Soils range from neutral to slightly basic clays and clay loams on the Rolling Blackland and Shallow Sites to acid sandy clay loams and loams on the Claypan Prairie Range Site (Table 1). The Claypan Prairie Range Site is typified by Laparita soils on nearly level to gently sloping uplands usually in proximity to small drainages. A claypan is prominent at 15 to $30 \mathrm{~cm}$ deep. The Rolling Blacklands Range Site is characterized by Monteola soils, and gently undulates with occasional slopes to $8 \%$. Fashing soils typify the Shallow Range Site which generally occurs on gently sloping to convex surfaces with gradients of 1 to $5 \%$.

A third experiment was conducted near Cotulla, about $100 \mathrm{~km}$ south of San Antonio. The site near Cotulla is Rolling Hardland dominated by blackbrush acacia. Soil is predominatly LaSalle Clay with frequent rock outcrops.

\section{Methods}

Experiments at Campbellton were designed as randomized complete blocks arranged as split blocks. Shredding was compared to no shredding as main plot effects, and picloram pellet treatments were applied to 1.5-ha subplots. The treatments were triplicated in an experiment installed on May 17, 1976. Treatments were duplicated in another experiment installed on May 25, 1977, immediately adjacent to the 1976 experiment. Main plots were shredded on January 30, 1976, or on May 1, 1977. The 5 and $10 \%$ formulations of picloram pellets (approximately 1.6 and $2.4 \mathrm{~mm}$ diam, respectively) were applied at $0,1.1$, or $2.2 \mathrm{~kg} / \mathrm{ha}$ (active ingredient) with fixed wing aircraft, except in the 1977 experiment where 1.1 and $1.6 \mathrm{~kg} / \mathrm{ha}$ of the $10 \%$ formulation were applied. Picloram pellets were applied in $13.7 \mathrm{~m}$-wide swaths with a spreader attachment used for aerial application of fertilizer and seeds. Experiments (years) were statistically analyzed separately.

In 1976, each suplot was stratified into range sites for vegetation sampling. Composition of the woody plant communities were determined prior to treatment using the point-center-quarter method (Cottam and Curtis 1956) at 25, equally spaced points on a 270-m line down the center of each plot. The lines were resampled at 13 months after treatment to determine changes in canopy cover and percentage of woody plants killed following treatment. At 13, 26 , and 42 months after treatment, visual estimates of canopy cover reduction by species were recorded along the lines. The experiment installed in 1977 was evaluated 13 and approximately 30 months after treatment by estimating canopy cover reductions of woody plants by species along a line down the center of each subplot.

A weather station was installed in the center of the study area to monitor rainfall. Soils were sampled for characterization by range site from each main plot at 0 to 3,3 to 8,8 to 15,15 to 30 , and 30 to $45 \mathrm{~cm}$ deep. The samples were divided into two subsamples and textural components were determined by the hydrometer method, $\mathrm{pH}$ of a 1:2 slurry, and organic matter by acid digestion and titration.

On May 24, 1977, the 5\% formulation of picloram pellets was aerially applied at 1 and $2.4 \mathrm{~kg} /$ ha and the $10 \%$ formulation was applied at 1 and $2 \mathrm{~kg}$ / ha to the site near Cotulla. The pellets were applied in 12-m-wide swaths to 3-ha plots with each treatment duplicated in a randomized complete block design. Approximately 14 and 27 months after herbicide application, live canopy cover reduction of woody plants was estimated along a line down the center of each plot.

\section{Results and Discussion}

\section{Shredding/Picloram Pellet Combinations}

Average woody plant canopy cover $(62 \%)$ of undisturbed brush stands near Campbellton did not change appreciably during this study. The canopy cover was reduced to $11 \%$ on plots at 18 months after shredding only (Table 2). Pellet applications to undisturbed areas reduced the overall canopy cover to 19 to $25 \%$. Applications of picloram pellets to shredded plots did not significantly reduce the woody plant canopy cover after 13 months compared to that on plots shredded only or that on plots receiving the herbicide only. Also, analysis of variance did not indicate a significant shredding-by-herbicide interaction, regardless of evaluation time. Therefore, shredding and picloram pellet applications were additive rather than herbicide activity being increased on shredded areas compared to treatment to undisturbed brush. Since the same results were obtained from the experiment conducted in 1977, data from shredded and undisturbed plots were averaged for evaluation of susceptibility of individual brush species.

\section{Range Site Relationships}

There were no differences among range sites in reaction of

Table 2. Canopy cover of woody plants on shredded and unshredded South Texas Plains mixed-brush communities 13 months following aerial application of two rates and formulations of pelleted picloram near Campbellton in May 1976.

\begin{tabular}{cccc}
\hline \hline \multicolumn{2}{c}{ Picloram treatment } & \multicolumn{2}{c}{$\begin{array}{c}\text { Foliar cover (\%) by shredding } \\
\text { treatment }\end{array}$} \\
\cline { 3 - 4 } $\begin{array}{c}\text { Active ingredient } \\
(\%)\end{array}$ & $\begin{array}{c}\text { Rate } \\
(\mathrm{kg} / \mathrm{ha})\end{array}$ & & \multicolumn{2}{c}{ Shredded ${ }^{2}$} & Undisturbed \\
\hline 0 & 0 & $11 \mathrm{a}$ & $62 \mathrm{~b}$ \\
5 & 1.1 & $6 \mathrm{a}$ & $25 \mathrm{a}$ \\
10 & 1.1 & $6 \mathrm{a}$ & $20 \mathrm{a}$ \\
5 & 2.2 & $7 \mathrm{a}$ & $19 \mathrm{a}$ \\
10 & 2.2 & $7 \mathrm{a}$ & $22 \mathrm{a}$ \\
\hline
\end{tabular}

${ }^{1}$ Means within the picloram/shredding interaction set or within an average response row or column followed by the same letter are not significantly different at the .05 level according to Duncan's multiple range test.

${ }^{2}$ Plots shredded in January 1976. 
Table 3. Average canopy reduction and percentage twisted acacia completely defoliated on the Rolling Blackland, Claypan Prairie and the Shallow Site 13 months following aerial application of two rates and formulations of pelleted picloram near Campbellton in May 1976.1

\begin{tabular}{|c|c|c|c|c|c|}
\hline \multicolumn{2}{|c|}{ Picloram treatment } & \multicolumn{2}{|c|}{$\begin{array}{c}\text { Rolling Blackland } \\
\text { and Claypan Prairie } \\
\end{array}$} & \multicolumn{2}{|c|}{ Shallow } \\
\hline $\begin{array}{c}\text { Active } \\
\text { ingredient } \\
(\%) \\
\end{array}$ & $\begin{array}{c}\text { Rate } \\
(\mathrm{kg} / \mathrm{ha})\end{array}$ & $\begin{array}{l}\text { Avg canopy } \\
\text { reduction } \\
(\%)\end{array}$ & $\begin{array}{c}\text { Complete } \\
\text { defoliation } \\
(\%)\end{array}$ & $\begin{array}{l}\text { Avg canopy } \\
\text { reduction } \\
(\%)\end{array}$ & $\begin{array}{c}\text { Complete } \\
\text { defoliation } \\
(\%)\end{array}$ \\
\hline- & 0 & $0 \mathrm{a}$ & $0 \mathrm{r}$ & $9 \mathrm{a}$ & $0 \mathrm{r}$ \\
\hline 5 & 1.1 & $19 a b$ & $4 \mathrm{r}$ & $65 \mathrm{~d}$ & $30 \mathrm{~s}$ \\
\hline 10 & 1.1 & $36 \mathrm{bc}$ & $4 r$ & $68 \mathrm{~d}$ & $36 \mathrm{~s}$ \\
\hline 5 & 2.2 & $42 \mathrm{c}$ & $4 \mathrm{r}$ & $73 \mathrm{~d}$ & $47 \mathrm{~s}$ \\
\hline 10 & 2.2 & $21 \mathrm{~b}$ & $5 r$ & $72 \mathrm{~d}$ & $52 \mathrm{~s}$ \\
\hline
\end{tabular}

'Canopy reduction or complete defoliation means followed by the same letter are not significantly different at the .05 level according to Duncan's multiple range test.

the woody species to the pelleted picloram except with twisted acacia (Table 3). Percentage canopy reduction of twisted acacia following application of picloram pellets in 1976 was lower on Rolling Blackland and Claypan Prairie Sites than on Shallow Sites. Twisted acacia plants completely defoliated on Shallow Sites ranged from 30 to $52 \%$ of the population with no significant difference among picloram treatments. Few plants on Rolling Blackland or Claypan Prairie Range Sites were completely defoliated. This differential response was difficult to explain since organic matter and clay contents were similar among the sites (Table 1). However, because of this interaction, the response of twisted acacia was not reported across range sites. Response of other species was averaged over range sites for discussion of relative susceptibilities. The Shallow Sites composed about $75 \%$ of the 1976 experimental area and essentially all of the 1977 experimental area.

Response of twisted acacia in 1977 was similar to that reported from the experiment in 1976. Canopy reduction of twisted acacia was $55 \%$ and $76 \%$ at 13 months after applications of $1.1 \mathrm{~kg} / \mathrm{ha}$ of the $5 \%$ and $10 \%$ formulation, respectively, of picloram pellets to Shallow Sites in 1977 (data not shown). In the same study, $1.6 \mathrm{~kg} /$ ha of the $10 \%$ formulation reduced the twisted acacia canopies by $80 \%$, and $2 \mathrm{~kg} / \mathrm{ha}$ of the $5 \%$ formulation reduced the canopies of $82 \%$. Twisted acacia plants completely defoliated ranged from 15 to $25 \%$ of the population where the lower rate was applied, and from 30 to $40 \%$ where the higher rate was applied in 1977 , regardless of picloram pellet formulation. Canopy reduction averaged less than $15 \%$ by 30 months after application of the higher rates of the picloram pellets but the twisted acacia treated with the lower rates had completely recovered.

\section{Relative Susceptibility of Woody Plants}

The study area near Campbellton was extremely dry at the time the study was initiated. No significant rainfall had occurred during the 60 days prior to herbicide application in 1976. However, almost $16 \mathrm{~cm}$ of rainfall were received the 30 days following application of picloram pellets. This a mount of rainfall was considered adequate for movement of the herbicide into the soil and for root uptake of the chemical. Almost $120 \mathrm{~cm}$ of rainfall were received during the 12 month period following pellet applications. Over $15 \mathrm{~cm}$ of rainfall were received during the 30 -day period following application of the pellets in 1977 and $100 \mathrm{~cm}$ were received by 13 months after application. Therefore, rainfall condi- tions at the Campbellton study site were considered conducive to activity of soil-applied herbicides. In contrast, $13 \mathrm{~cm}$ of rainfall were received the month following application of the pellets near Cotulla but total rainfall was only $39 \mathrm{~cm}$ for the year following installation of the experiment.

Spiny hackberry was the most susceptible woody species to picloram pellets. At 60 days after herbicide application, the spiny hackberry canopy was reduced by $85 \%$ where the picloram pellets were applied, regardless of rate and averaged across formulations (data not shown). The $2.2 \mathrm{~kg} / \mathrm{ha}$ rate of either pellet formulation completely eliminated spiny hackberry canopies 13 months after 1976 applications, and reduced the canopies by 96 and $98 \%$ following applications in 1977 (Table 4). At 26 months after applications of the pellets in 1976, spiny hackberry canopy reductions exceeded $90 \%$ (Table 5), and more than $85 \%$ of the spiny hackberry plants were apparently dead (data not shown), regardless of herbicide rate or formulation. After 14 months and with less than half the rainfall $(58 \mathrm{~cm})$ occurring on the Campbellton site, canopy cover of spiny hackberry was eliminated by the picloram pellets near Cotulla (data not shown). All picloram pellet treatments had completely controlled the spiny hackberry at 42 months after application in 1976, and canopy reduction ranged from 93 to $100 \%$ at 30 months after installation of the experiment near Campbellton in 1977. At 27 months after application of the picloram pellets near Cotulla, canopy reduction of spiny hackberry exceeded $90 \%$, regardless of herbicide rate of formulation. Control of spiny hackberry with picloram pellets at all locations was similar to that reported after application of picloram sprays at 1.1 or $2.2 \mathrm{~kg} / \mathrm{ha}$ in the fall (Bovey et al. 1970) or in the spring (Meadors et al. 1978).

Blackbrush acacia is susceptible to sprays containing picloram alone or picloram $+2,4,5$ - $\mathrm{T}$ applied in the spring or in the fall (Bovey et al. 1970). At 60 days after applying 1.1 $\mathrm{kg} / \mathrm{ha}$ of the picloram pellets near Campbellton in 1976, blackbrush acacia canopies were reduced by slightly more than 50\% (data not shown). Percentage canopy reduction after application of $2.2 \mathrm{~kg}$ / ha was variable, but the higher rate of the $5 \%$ formulation reduced the canopy cover of blackbrush acacia by $96 \%$ after 60 days. The $2.2 \mathrm{~kg} /$ ha rate of picloram pellets reduced the blackbrush canopies by 65 to $79 \%$ after 13 months with little difference between years of application (Table 4). The control levels were similar to those reported by Bovey, Baur and Morton (1970) following application of picloram sprays at 1.1 to $2.2 \mathrm{~kg}$ / ha in the fall. The $1.1 \mathrm{~kg} / \mathrm{ha}$ rate of picloram pellets tended to be less effective, regardless of formulation, than $2.2 \mathrm{~kg} /$ ha both years of application (Table 4). Meadors et al. (1978) reported that sprays of $2,4,5-\mathrm{T}+$ picloram at $1.1 \mathrm{~kg} /$ ha were more effective than the same rate of picloram pellets for blackbrush acacia control.

Recovery of blackbrush acacia was apparent after 26 months where $1.1 \mathrm{~kg} / \mathrm{ha}$ of the picloram pellets were applied near Campbellton but canopy reduction exceeded $60 \%$ where $2.2 \mathrm{~kg} /$ ha were applied (Table 5). After 26 months 5 to $12 \%$ of the blackbrush acacia plants were completely defoliated by $1.1 \mathrm{~kg} / \mathrm{ha}$ of the picloram pellets whereas $42 \%$ of the blackbrush acacia plants were completely defoliated by 2.2 $\mathrm{kg} /$ ha (data not shown). After 27 months near Cotulla, canopy reduction averaged $22 \%$ where the lower rates of picloram pellets were applied but varied from $40 \%$ to $80 \%$ where 2 and $2.4 \mathrm{~kg} /$ ha of herbicide were applied, respec- 
Table 4. Canopy reduction of eight woody species 13 months after aerial application of picloram pellets to South Texas mixed brush in May 1976 and May 1977 near Campbellton.

Picloram treatment

\begin{tabular}{|c|c|c|c|c|c|c|c|c|c|}
\hline \multirow{2}{*}{$\begin{array}{l}\text { Active } \\
\text { ingredient } \\
(\%)\end{array}$} & \multirow[b]{2}{*}{$\begin{array}{l}\text { Rate } \\
\text { (kg/ha) }\end{array}$} & \multicolumn{8}{|c|}{ Canopy reduction $(\%)^{1}$} \\
\hline & & Agarito & $\begin{array}{l}\text { Blackbrush } \\
\text { acacia }\end{array}$ & $\begin{array}{l}\text { Desert } \\
\text { yaupon }\end{array}$ & $\begin{array}{l}\text { Honey } \\
\text { mesquite }\end{array}$ & Lotebush & $\begin{array}{l}\text { Prickly- } \\
\text { pear }\end{array}$ & $\begin{array}{l}\text { Spiny } \\
\text { hackberry }\end{array}$ & $\begin{array}{l}\text { White- } \\
\text { brush }\end{array}$ \\
\hline \multicolumn{10}{|c|}{1976 Application } \\
\hline- & 0 & $2 \mathrm{a}$ & $6 \mathrm{ab}$ & $3 \mathrm{a}$ & $0 \mathrm{a}$ & $4 \mathrm{a}$ & 14 a-d & $9 a b$ & 13 a-d \\
\hline 5 & 1.1 & $11 \mathrm{~d}$ & $61 \mathrm{hi}$ & $5 \mathrm{ab}$ & $0 \mathrm{a}$ & $13 \mathrm{a}-\mathrm{d}$ & $41 \mathrm{efg}$ & $98 \mathrm{kl}$ & 35 efg \\
\hline 5 & 2.2 & $30 \mathrm{~d}-\mathrm{f}$ & $74 \mathrm{ij}$ & $44 \mathrm{fgh}$ & $0 \mathrm{a}$ & 29 cde & $84 \mathrm{jkl}$ & 1001 & $87 \mathrm{jkl}$ \\
\hline 10 & 1.1 & $10 \mathrm{abc}$ & $51 \mathrm{gh}$ & $10 \mathrm{abc}$ & $0 \mathrm{a}$ & $13 a-d$ & $54 \mathrm{gh}$ & $98 \mathrm{kl}$ & $77 \mathrm{ij}$ \\
\hline 10 & 2.2 & $24 \mathrm{~b}-\mathrm{e}$ & $79 \mathrm{ijk}$ & 34 efg & $1 \mathrm{a}$ & $30 \mathrm{def}$ & $74 \mathrm{ij}$ & 1001 & $88 \mathrm{jkl}$ \\
\hline \multicolumn{10}{|c|}{1977 Application } \\
\hline- & 0 & 0 a & $0 \mathrm{a}$ & 0 a & $0 \mathrm{a}$ & $0 \mathrm{a}$ & - & $0 \mathrm{a}$ & $0 \mathrm{a}$ \\
\hline 5 & 1.1 & $4 \mathrm{a}$ & $44 \mathrm{~cd}$ & $3 \mathbf{a}$ & $0 \mathrm{a}$ & $13 \mathrm{ab}$ & - & $78 \mathrm{fg}$ & $35 \mathrm{bc}$ \\
\hline 5 & 2.2 & $10 a b$ & 65 ef & $14 a b$ & $3 a$ & $36 \mathrm{bcd}$ & - & $98 \mathrm{~h}$ & $44 \mathrm{~cd}$ \\
\hline 10 & 1.1 & $9 \mathrm{a}$ & $38 \mathrm{bcd}$ & $2 \mathrm{a}$ & $0 \mathrm{a}$ & $14 \mathrm{ab}$ & - & $78 \mathrm{fg}$ & $40 \mathrm{~cd}$ \\
\hline 10 & 1.6 & $8 \mathrm{a}$ & 73 ef & $15 \mathrm{ab}$ & $0 \mathrm{a}$ & $30 \mathrm{bc}$ & - & $96 \mathrm{gh}$ & $56 \mathrm{de}$ \\
\hline
\end{tabular}

'Means within an experiment followed by the same letter are not significantly different at the .05 level according to Duncan's multiple range test.

tively. However, the blackbrush acacia had completely recovered, regardless of picloram treatment, at 42 months after application in 1976. Only scattered plants had not recovered completely from the picloram treatments at 30 months after application in 1977 .

The lower rate of the picloram pellets reduced the blackbrush acacia canopies by 14 to $25 \%$ after 14 months near Cotulla (data not shown). At $2 \mathrm{~kg} / \mathrm{ha}$, the $10 \%$ formulation reduced the canopies of blackbrush acacia by $45 \%$ and killed $10 \%$ of the plants. The $5 \%$ formulation, applied at $2.4 \mathrm{~kg} / \mathrm{ha}$ reduced the canopies by $90 \%$ and completely defoliated $65 \%$ of the blackbrush acacia plants in the experiment near Cotulla.

Initial response of pricklypear was erratic, especially to the lower rates of picloram pellets the year of application near Campbellton. Also insect damage complicated isolation of initial herbicide effects. However, the response of pricklypear was fairly uniform at 1 year after treatment. Green cladophyll area of pricklypear was reduced by 74 to $84 \%$ by 13 months after applying $2.2 \mathrm{~kg} /$ ha of the picloram pellets in 1976 (Table 4). Pricklypear control improved 2 years after application of the low rate of the pellets compared to the earlier evaluations. Green cladophyll area reduction of pricklypear exceeded $70 \%$ where $1.1 \mathrm{~kg} /$ ha of the pellets were applied and was greater than $95 \%$ where the higher rate was applied. About $70 \%$ of the pricklypear plants were killed by $1.1 \mathrm{~kg} / \mathrm{ha}$ of the picloram pellets and $85 \%$ were killed by the high application rate, regardless of formulation (data not shown). At 42 months after application of the picloram pellets, pricklypear was completely controlled, regardless of application rate of formulation. Pricklypear occurrence was not adequate for evaluation following applications of treatments near Campbellton in 1977 or in the experiment near Cotulla.

Within 60 days after application of the picloram pellets at $1.1 \mathrm{~kg} /$ ha near Campbellton, whitebrush canopies were reduced by $42 \%$, and by about $60 \%$ where $2.2 \mathrm{~kg}$ / ha were applied (data not shown). Whitebrush response varied somewhat between experiments near Campbellton based on evaluations 13 months after application. Picloram pellets applied at $2.2 \mathrm{~kg} /$ ha in 1976 reduced the whitebrush canopies by more than $85 \%$. At 13 months after application of the high rates of the pellets in 1977, canopy reduction was 44 to $56 \%$. The low rate did not reduce the whitebrush canopies by more than $40 \%$ except where the $10 \%$ formulation was applied in 1977. Whitebrush control was reduced at 26 months after application compared to earlier evaluations (Table 5). At $1.1 \mathrm{~kg} /$ ha, no whitebrush defoliation occurred where the $10 \%$ formulation was applied, and canopy reduction was only $29 \%$ where the $5 \%$ formulation was used. Average canopy reduction varied from 53 to $61 \%$ where 2.2 $\mathrm{kg} /$ ha of the picloram pellets were applied with $11 \%$ of the plants completely defoliated. By 30 months and 42 months after application of the picloram pellets in 1977 and 1976, respectively, the whitebrush had completely recovered, regardless of rate or formulation.

The low rate of picloram pellets was not highly effective for control of agarito, desert yaupon or lotebush, regardless of year of treatment, herbicide formulation, or time of evaluation. The high rates reduced the canopies of agarito by 24 to $30 \%$ at 13 months following 1976 treatments near Campbellton but were ineffective following applications of the pellets in 1977 (Table 4). The agarito canopies had recovered about 26 months (Table 5) and no agarito plants were killed

Table 5. Canopy reduction of eight woody species at 26 months after aerial application of picloram pellets to South Texas mixed brush in May 1976 near Campbellton.

\begin{tabular}{|c|c|c|c|c|c|c|c|c|c|}
\hline \multicolumn{2}{|c|}{ Picloram treatment } & \multicolumn{8}{|c|}{ Canopy reduction $(\%)^{1}$} \\
\hline $\begin{array}{l}\text { Active } \\
\text { ingredient } \\
(\%)\end{array}$ & $\begin{array}{l}\text { Rate } \\
(\mathrm{kg} / \mathrm{ha})\end{array}$ & Agarito & $\begin{array}{l}\text { Blackbrush } \\
\text { acacia }\end{array}$ & $\begin{array}{l}\text { Desert } \\
\text { yaupon }\end{array}$ & $\begin{array}{l}\text { Honey } \\
\text { mesquite }\end{array}$ & Lotebush & Pricklypear & $\begin{array}{l}\text { Spiny } \\
\text { hackberry }\end{array}$ & Whitebrush \\
\hline $\begin{array}{l}- \\
5 \\
5 \\
10 \\
10\end{array}$ & $\begin{array}{c}0 \\
1.1 \\
2.2 \\
1.1 \\
2.2\end{array}$ & $\begin{array}{l}0 \mathrm{a} \\
2 \mathrm{a} \\
13 \mathrm{abc} \\
13 \mathrm{ab} \\
13 \mathrm{abc}\end{array}$ & $\begin{array}{l}1 \mathrm{a} \\
22 \mathrm{bcd} \\
73 \mathrm{hi} \\
17 \mathrm{abc} \\
62 \mathrm{ghi}\end{array}$ & $\begin{array}{l}3 \mathrm{ab} \\
6 \mathrm{ab} \\
41 \mathrm{def} \\
19 \mathrm{abc} \\
47 \mathrm{ef}\end{array}$ & $\begin{array}{l}0 \mathrm{a} \\
0 \mathrm{a} \\
1 \mathrm{a} \\
0 \mathrm{a} \\
0 \mathrm{a}\end{array}$ & $\begin{array}{c}0 \mathrm{a} \\
3 \mathrm{ab} \\
7 \mathrm{ab} \\
4 \mathrm{ab} \\
32 \mathrm{cde}\end{array}$ & $\begin{array}{c}0 \mathrm{a} \\
75 \mathrm{hi} \\
98 \mathrm{k} \\
73 \mathrm{hi} \\
96 \mathrm{jh}\end{array}$ & $\begin{array}{c}0 \mathrm{a} \\
93 \mathrm{jk} \\
91 \mathrm{ijk} \\
94 \mathrm{jk} \\
91 \mathrm{ijk}\end{array}$ & $\begin{array}{c}5 \mathrm{ab} \\
29 \mathrm{cde} \\
61 \mathrm{gh} \\
0 \mathrm{a} \\
53 \mathrm{fg}\end{array}$ \\
\hline
\end{tabular}

${ }^{1}$ Means followed by the same letter are not significantly different .05 level according to Duncan's multiple range test. 
(data not shown).

Initial response of desert yaupon was similar to that of agarito. After 13 months, the $1.1 \mathrm{~kg} /$ ha did not significantly reduce desert yaupon canopies in either experiment near Campbellton, and the high rate was only partially effective following 1976 applications (Table 4). However, canopy reduction in the 1976 experiment at 26 months after application of $2.2 \mathrm{~kg} /$ ha was similar to results after 13 months (Table 5). Desert yaupon canopies were completely restored at 30 and 42 months after application of the picloram pellets in 1977 and 1976, respectively.

The canopies of lotebush were essentially unaffected at 60 days after picloram applications. Lotebush response after 13 months was similar between experiments near Campbellton, and the higher picloram rate reduced the canopies by 29 to $36 \%$ (Table 4). After 26 months, $2.2 \mathrm{~kg} /$ ha of the $10 \%$ formulation had significantly reduced the lotebush canopies, but by only $32 \%$ (Table 5). Lotebush canopies were completely restored at 30 and 42 months after application of the picloram pellets in 1977 and 1976, respectively.

Based on results of these studies, spiny hackberry and pricklypear are apparently highly susceptible to picloram pellets. However, pricklypear responds more slowly than spiny hackberry. Blackbrush acacia, susceptible to sprays containing picloram (Meadors et al. 1978), is not highly susceptible to picloram pellets on sites most favorable for control. Agarito, desert yaupon, lotebush, and whitebrush were not effectively controlled by picloram pellets. As in experiments by Bovey et al. (1969), honey mesquite was tolerant of picloram pellets in this study, regardless of formulation or time of evaluation (Tables 4,5 ). There was no difference in the response of creeping mesquite and honey mesquite to the picloram pellets.

These data do not indicate any advantage, relative to brush control, of the $5 \%$ formulation of picloram pellets compared to $10 \%$ formulation. The $10 \%$ formulation would be advantageous logistically in that less formulated herbicide must be transported, handled, and applied to achieve the desired application rate of active ingredient.

The overall woody plant responses the growing season following pellet applications in the spring were not adequate to release the herbaceous understory (Kitchen 1977). Lack of positive forage response until the second growing season after spring applications of tebuthiuron $[N-(5-[1,1-$ dimethylethyl]-1,3,4,-thiadiazol-2-yl)- $N, N^{\prime}$-dimethylurea] pellets to mixed-brush stands was also reported (Scifres and
Mutz 1978). In contrast, sprays applied in the spring may result in significant forage release, depending on rainfall, the season of application to mixed brush (Scifres et al. 1976). Compared to defoliation levels normally occurring within 30 days after the application of aerial sprays, the slow response of even the most susceptible brush to pellets must be considered a disadvantage.

\section{Literature Cited}

Bovey, R.W., H.L. Morton, R.E. Meyer, T.O. Flynt, and T.E. Riley. 1972. Control of yaupon and associated species. Weed Sci. 20: 246-249.

Bovey, R.W., J.R. Baur, and H.L. Morton. 1970. Control huisache and associated woody species in South Texas. J. Range Manage. 23: 47-50.

Bovey, R.W., H.L. Morton, J.R. Baur, J.D. Diaz-Colon, C.C. Dowler, and S.K. Lehman. 1969. Granular herbicides for woody plant control. Weed Sci. 17: 538-541.

Bovey, R.W., and C.J. Scifres. 1971. Residual characteristics of picloram in grassland ecosystems. Texas Agr. Exp. Sta. Bull. 1111. 24 p.

Cottam, G., and J.T. Curtis. 1956. The use of distance measures in phytosociological sampling. Ecology 27: 451-460.

Gordon, R.A. 1976. Burning/picloram combinations for Macartney rose control on the Texas Coastal Prairie. M.S. Thesis, Dep. Range Sci., Texas A\&M Univ., College Station. 73 p.

Kitchen, L.M. 1977. Response of South Texas Plains mixed-brush communities to pelleted picloram. M.S. Thesis, Dep. Range Sci., Texas A\&M Univ., College Station. 89 p.

Meadors, C.H., R.W. Jacoby, and C.E. Fisher. 1978. Control of south Texas brush with liquid and pelletized herbicides. Proc. So. Weed Sci. Soc. 31: 315 .

Meyer, R.E., R.W. Bovey, and J.R. Baur. 1978. Control of an oak (Quercus) complex with herbicide granules. Weed Sci. 26: 444-453.

Meyer, R.E., R.W. Bovey, T.E. Riley, and T.O. Flynt. 1976. Seasonal responsc of Macartncy rose and huisache to herbicides. J. Range Manage. 29: 157-160.

Robison, E.D., and B.T. Cross. 1970. Redberry juniper control and grass response following aerial application of picloram. Texas Agr. Exp. Sta. PR-2805: 20-22.

Scifres, C.J. 1972a. Redberry juniper control with soil-applied herbicides, J. Range Manage. 25: 308-310.

Scifres, C.J. 1972b. Response of sand shinnery oak to dicamba granules and picloram pellets. J. Range Manage. 25: 115-156.

Scifres, C.J. (Ed). 1973). Mesquite. Growth and development, management, economics, control, uses. Texas Agr. Exp. Sta. Res. Mon. 1.84 p.

Scifres, C.J. 1975a. Fall application of herbicide improves Macartney rose-infested Coastal Prairie rangeland. J. Range Manage. 28: 483-486.

Scifres, C.J. 1975b. Texas persimmon distribution and control with individual plant treatments. Texas Agr. Exp. Sta. Bull. 1157. 12 p.

Scifres, C.J., and M.M. Kothmann. 1976. Site relations, regrowth characteristics and control of lotebush with herbicides. J. Range Manage. 29: 154-156.

Scifres, C.J., G.P. Durham, and J.L. Mutz. 1977. Range forage production and consumption following aerial spraying of mixed brush. Weed Sci. 25: $48-54$.

Scifres, C.J., and J.L. Mutz. 1978. Herbaceous vegetation changes following applications of tebuthiuron for brush control. J. Range Manage. 31: 375-378.

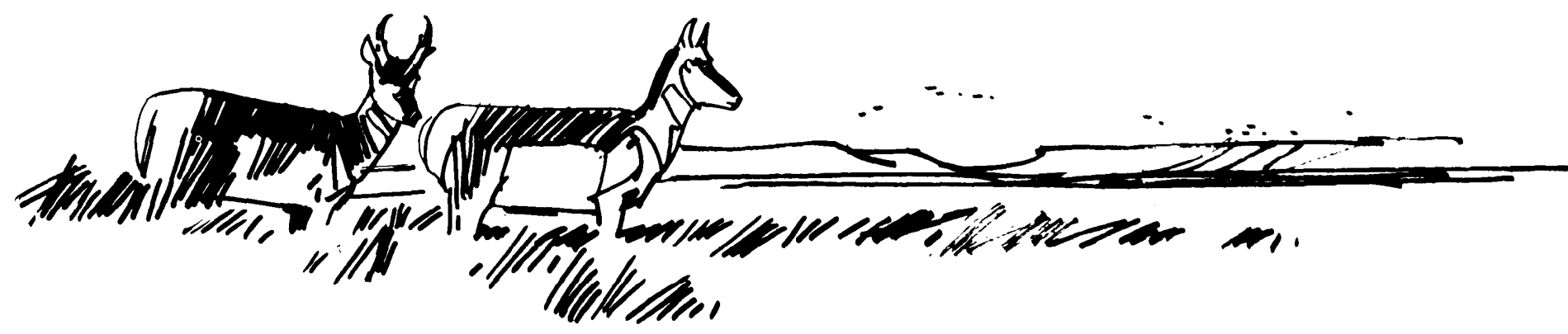

